\title{
Swyer-James-Macleod Syndrome and
Antiphospholipid Antibody Syndrome: A Rare Case Report
}

\section{Swyer-James-Macleod Sendromu ve Antifosfolipid Antikor Sendromu: Nadir Bir Olgu Sunumu}

Melike Yüksel Yavuz', Ahmet Daylan²

\section{Abstract}

Swyer-James-Macleod syndrome (SJMS) is an entity of obliterative bronchiolitis, the etiology of which has been linked to childhood infections of the lower respiratory tract. Patients may not be diagnosed until older ages, and is based on noninvasive thoracic imaging methods and under the guidance of the patients' history. Antiphospholipid antibody syndrome (AFAS) is a multisystemic autoimmune disease that manifests with recurrent vascular thrombosis, unexplained fetal losses and thrombocytopenia, with 70\% of cases being female. It should also be kept in mind in the differential diagnosis of recurrent or unusual thrombosis and unprovoked thrombosis at young ages. A 33-year-old male patient who presented with acute peripheral thrombus underwent a pulmonologist consultation due to dyspnea, and was diagnosed with SJMS. After further investigations during follow-up, the patient was diagnosed with AFAS. We report on this case due to the synchronous coexistence of these two rare syndromes.

Key words: Swyer-James-Macleod Syndrome, Antiphospholipid antibody syndrome, deep vein thrombosis.

\section{Özet}

Swyer-James-Macleod sendromu (SJMS), etiyolojisinde çocukluk çağı alt solunum yolu enfeskiyonlarının yer aldığı düşünülen obliteratif bronşiolitis durumudur. Hastalar ileri yaşlara kadar tanı alamayabilir. Noninvaziv toraks görüntüleme yöntemleri ve öykü ile tanısı konulmaktadır. Antifosfolipid antikor sendromu (AFAS) tekrarlayan vasküler tromboz, nedeni açıklanamayan fetal kayıplar ve trombositopeni ile seyreden multisistemik otoimmün bir hastalıktır. Hastaların yüzde 70'i kadındır. Erkek hastalar için de tekrarlayan veya olağan dışı trombozlarda ve genç yaştaki unprovake trombozu olan olgularda ayırıcı tanıda akılda tutulmalıdır. Akut periferik trombüs klinik tablosunda başvuran 33 yaşındaki erkek olgu dispne nedeniyle göğüs hastalıklarına konsülte edildi ve SJMS tanısı aldı. Takiplerde, yapılan ileri tetkikler sonrasında, hastaya AFAS tanısı konuldu. Olgumuz, nadir görülen bu iki sendromun eş zamanlı birlikteliği nedeniyle bildirilmiştir.

Anahtar Sözcükler: Swyer-James-Macleod Sendromu, Antifosfolipid Antikor Sendromu, derin ven trombozu.

\footnotetext{
'Department of Chest Diseases, İzmir Çiğli Training and Research Hospital, İzmir, Turkey

'İzmir Çiğli Eğitim ve Araştırma Hastanesi, Göğüs Hastalıkları Bölümü, İzmir

2Department of Cardiovascular Surgery, İzmir Çiğli Training and Research Hospital, İzmir, Turkey Cerrahisi Bölümü, İzmir
}

Submitted (Başvuru tarihi): 12.08.2020 Accepted (Kabul tarihi): 12.12.2020

Correspondence (iletişim): Melike Yüksel Yavuz, Department of Chest Diseases, İzmir Çiğli Training and Research Hospital, i̇zmir, Turkey

e-mail: yukselmelike@windowslive.com 
Swyer-James-Macleod syndrome (SJMS) is a rare cause of unilateral hyperlucent lung, and is associated with hypoplasia of the ipsilateral peripheral pulmonary vessels and decreased vascularity (1). Although it is mostly asymptomatic, patients may present with cough, exertional dyspnea, and hemoptysis. It is thought to be attributable to bronchiolitis obliterans resulting from repetitive childhood infections (2). A study conducted in 2011 reported a prevalence of $0.01 \%$ (3). Antiphospholipid antibody syndrome (AFAS) is a multisystemic autoimmune disease that is characterized by recurrent vascular thrombosis and pregnancy losses due to the autoantibodies that develop against the phospholipid parts of proteins. No relationship between SJMS and AFAS has been previously reported in literature, and these diseases do not increase the frequency of each other. We report here on a male patient with SJMS in whom phlegmasia cerulea dolens was detected, and who was later diagnosed with AFAS, due to the coexistence of these rare diseases.

\section{CASE}

A 33-year-old male patient was referred from an external health facility having been diagnosed with deep vein thrombosis (DVT) and pulmonary embolism due to the sudden onset of widespread pain and discoloration in the left leg. The patient described no additional symptoms other than occasional shortness of breath for the last 15 days. He stated that he was working in accounting and had no smoking history. He had bronchitis and pneumonia attacks in childhood, and was under long-acting beta 2 agonists + inhaler corticosteroid treatment with an asthma diagnosis. He described no other comorbidity. No characteristics were identified when risk factors for pulmonary embolism and DVT were questioned. The patient had no previous history of thrombosis, and there was no thrombophilia in his family history. Upon physical examination, the patient was found to be dyspneic, tachypneic and tachycardic. Bilateral respiratory sounds were reduced. During an extremity examination, it was observed that the diameter of the left lower extremity was greater than that of the right, and was cold and cyanotic, and the patient had pain in the lower extremity. Motor and sensory loss was noted in the rural area and feet. The left femoral and popliteal pulses were palpable, while the pulse of the left anterior tibial artery and the posterior tibial artery were non-palpable, nor could they be monitored with a hand Doppler. Body temperature was $36.5^{\circ} \mathrm{C}$, blood pressure was $120 / 75 \mathrm{mmHg}$ and heart rate was $123 / \mathrm{min}$. The patient received $4 \mathrm{lt} / \mathrm{min}$ of oxy- gen, and his saturation was 98\%. Hypocapnia was present in the arterial blood gas. The creatinine level was $1.65 \mathrm{mg} / \mathrm{dl}$, the white blood cell count was 32,400 with neutrophil dominance, and D-dimer was $4400 \mathrm{mi}$ crograms/l. Other blood parameters were normal, and the Troponin I level was normal.

No conventional chest X-ray was carried out. Since optimal enhancement could not be achieved in a thorax angiography computed tomography (CT) of the patient, the pulmonary phase was insufficient, and the pulmonary arteries could not be evaluated clearly. The suspected filling defect at the atriocaval junction of the vena cava superior was consistent with the pulsation artefact. The left lung parenchyma was hyperlucent, the pulmonary vessel and sub-branches were hypoplasic, and there was a marked decrease in vascular branching (Figures 1-2). These findings were consistent with SJMS when evaluated with the anamnesis. The ejection fraction was $60 \%$, RV diameters were normal, sPAP was $25 \mathrm{mmHg}$ and firstdegree mitral and tricuspid valve insufficiency was identified on echocardiography. In lower extremity color venous Doppler ultrasonography (CDUS), acute thrombosis findings were observed in the left femoral, popliteal and deep crural veins. No flow was observed in the left popliteal artery or distal of the arterial system via CDUS. No opaque filling was observed in the left popliteal artery, left anterior or posterior tibial artery, or the peroneal arteries in a bilateral lower extremity angiography CT. Upon a diagnosis of phlegmasia cerulean dolens being made by cardiovascular surgeons, pharmaco-mechanical thrombolysis was planned for emergency decompression. In this picture, it may start with sudden and severe extremity pain and cause ischemia as a result of swelling, cyanosis, compartment syndrome, venous gangrene and arterial circulation disorder. The patients the leg had developed an edematous appearance. Five $\mathrm{mg}$ of alteplase was administered during the procedure, and continued via a catheter with a dosage of $1 \mathrm{mg} / \mathrm{h}$ selectively to the left main and external iliac veins within 2 hours. Following the procedure, the diameter difference between the legs regressed, and the distal pulses became palpable. Although there was no indication of filling defects suggesting thrombus in the pulmonary arteries due to pulmonary phase insufficiency on thorax CT angiography, it was observed that the tachycardia of the patient improved during thrombolytic administration. Pulmonary embolism could not be excluded, but the diagnosis was rejected due to the other supporting findings. After the patient developed hematuria, alteplase was discontinued, and 
enoxaparin was started subcutaneously at a dose of 0.8 mg twice a day. No pathology was found in renal CDUS. An abdominal USG performed due to hematuria was reported as normal. The patients' symptoms regressed, he had no respiratory failure in room air, and his ischemia findings and the difference in diameter between his legs disappeared. Accordingly, a diagnosis of antiphospholipid syndrome was made during follow-up.

\section{DISCUSSION}

SJMS, first described in 1953, has been linked to infectious childhood diseases, with adenovirus, measles, Bordetella pertussis, tuberculosis, Mycoplasma pneumoniae, Respiratory syncytial virus and Influenza A being the main infection agents. Lung development is delayed due to the bronchiolitis obliterans associated with these factors (4). Although most cases are asymptomatic, they may experience recurrent childhood infections and asthma-like symptoms, as in our case. Similar to our case, a case presented in 2019 was followed up with a diagnosis of asthma for many years (5). Respiratory function tests (RFT) may detect a mixed disorder in patients with bronchiectasis, while irreversible obstructive disorder is usually detected with bronchodilators. Total lung capacity may be decreased (6). We did not perform RFT on our patient due to the simultaneous venous thrombus at the time of diagnosis and the suspicion of pulmonary embolism at the outset. Although routine, conventional chest radiography and CT methods seem sufficient for diagnosis, bronchoscopy to exclude endobronchial obstruction, ventilation/perfusion scintigraphy to show perfusion, CT angiography, and magnetic resonance angiography examinations for vascular imaging, can be used.

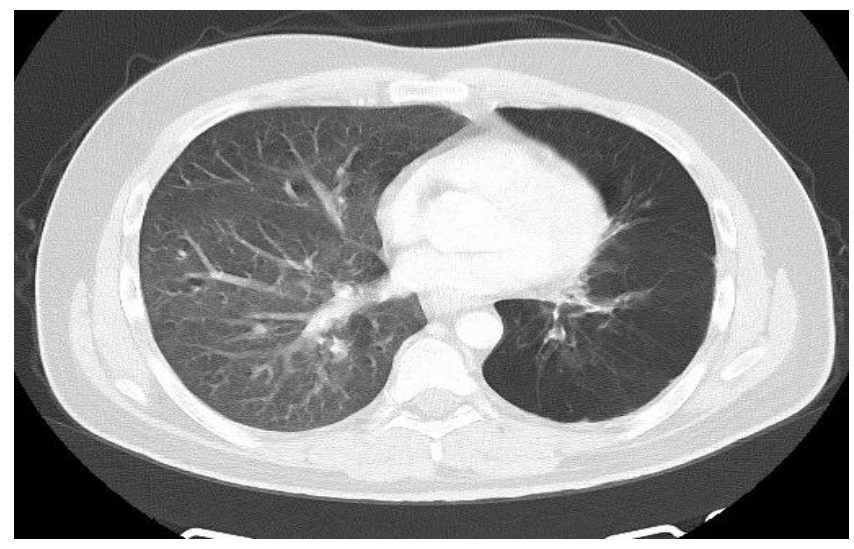

Figure 1: The left lung parenchyma was hyperlucent

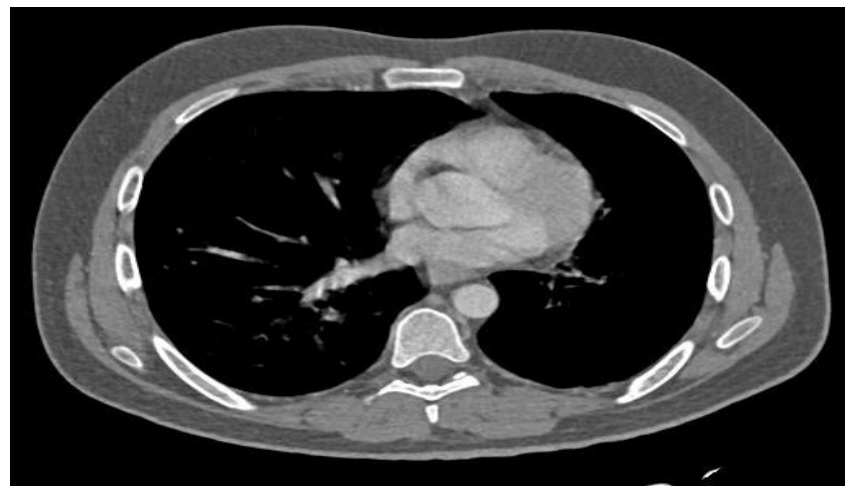

Figure 2: The pulmonary vessel and sub-branches were hypoplasic; there was a marked decrease in vascular branching

Şen et al. (7) reported diagnosing SJMS based on radiology and clinical data in referred patients who were thought to have a medium-probability pulmonary embolism on V/P scintigraphy. Cases typically have unilateral hyperlucency in the lung parenchyma. There are many factors involved in the etiology of unilateral hyperlucent lung, which is not related to the rotational technique problem. SAFE POEM, a widely adopted abbreviation in radiology-based sources, refers to SJMS, agenesis, fibrosis, effusion, pneumothorax, pneumonectomy, obstruction, pulmonary embolism and mucous plugs (8). It is vital to keep these in mind in a differential diagnosis. In such cases, the differential diagnosis should be made well in terms of lung pathologies since chronic thromboembolic events may cause a decrease in vascular diameters and the deletion of vascular structures in the parenchyma. The presence of the first thrombus attack in our case illuminated this situation. Cases with SJMS with bilateral hyperlucency have also been reported $(9,10)$. Bronchiectasis can also be seen in SJMS. As in the case of the 51 -yearold male presented by Dirweesh et al. (11) in 2017, cases with ipsilateral cystic bronchiectasis can present with chronic sputum production, recurrent lower respiratory tract infections and effort dyspnea. There was no bronchiectasis in our case. A decrease in peripheral pulmonary vascularization occurs due to inflammation. As in our case, ipsilateral small hilus, pulmonary artery hypoplasia and decreased pulmonary vascularity can be detected. A pulmonary arteriovenous malformation was found together with SJMS in two cases presented in 2012 and $2020(12,13)$. In a 46-year-old male case reported from Iran with the diagnosis of pulmonary hypertension (PHT), the condition was initially thought to be a chronic pulmonary embolism, but the case was subsequently diagnosed with SJMS (14). Our case did not have PHT. A single ostium coronary artery anomaly accompanied the clinical presentation in a 60-year-old patient in 2013 (15). Again, 
cases accompanied by the myocardial muscular bridge and ventricular septal defect are presented $(16,17)$. In the series reported on by Akgedik et al. (18), six patients who were further investigated for pulmonary embolism, were subsequently diagnosed with SJMS due to the similarity in clinical and basic radiological examinations at the beginning. The article stressed that SJMS should be kept in mind in the differential diagnosis of patients presenting with unilateral hyperlucency. In our case, although pulmonary embolism could not be ruled out at the beginning due to technical problems in thoracic CT angiography, we found the pulmonary arteries to have a bloodstream in subsequent imaging. It is known that thrombolytic treatment can be effective on early rapid recanalization and hemodynamics, and to contribute positively to the prevention of pulmonary hypertension in the late period $(19,20)$. Considering the effect of thrombolytic therapy on the imaging and clinical recovery of our patient, it was clear that the image of the filling defect in the right main pulmonary artery was compatible with the pulse artifact on the first imaging. In our case, venous thrombosis was also seen. This first thrombosis attack of the case was unprovoked, but it was later learned that the patient had been diagnosed with antiphospholipid antibody syndrome and was under rheumatology follow-up. The prevalence of AFAS in the general population is $2-4 \%$. It progresses with recurrent arterial or venous thromboembolism and with pregnancy (21), and usually affects young women of childbearing age. In male patients, as in our case, who was below the age of 50, patients should be referred when unprovoked venous and/or arterial thromboembolism are present and/or when thromboembolism is detected, particularly in unexpected areas (22). It is essential to follow up patients for pulmonary hypertension development. Cases that develop PHT are treated with lifelong thrombus prophylaxis. Autoantibody positivity is important in diagnosis, with the anti-cardiolipin antibody and antib2 glycoprotein antibody being found to be high in our case. The patient was diagnosed with AFAS based on clinical and laboratory data. A review of literature revealed no previous case with coexisting SJMS and AFAS.

\section{CONCLUSION}

SJMS should be considered in a differential diagnosis, especially in cases with unilateral hyperlucency with a history of recurrent childhood infections. In these cases, if pulmonary artery anomalies alone are identified, and an additional thrombophilia process is added, as in our case, more attention should be paid to possible PHT development.

\section{CONFLICTS OF INTEREST}

None declared.

\section{AUTHOR CONTRIBUTIONS}

Concept - M.Y.Y., A.D.; Planning and Design - M.Y.Y., A.D.; Supervision - M.Y.Y., A.D.; Funding - M.Y.Y.; Materials - M.Y.Y.; Data Collection and/or Processing M.Y.Y.; Analysis and/or Interpretation - M.Y.Y.; Literature Review - M.Y.Y.; Writing - M.Y.Y.; Critical Review - M.Y.Y

\section{YAZAR KATKILARI}

Fikir - M.Y.Y., A.D.; Tasarım ve Dizayn - M.Y.Y., A.D.; Denetleme - M.Y.Y., A.D.; Kaynaklar - M.Y.Y.; Malzemeler - M.Y.Y.; Veri Toplama ve/veya İşleme - M.Y.Y.; Analiz ve/veya Yorum - M.Y.Y.; Literatür Taraması - M.Y.Y.; Yazıyı Yazan - M.Y.Y.; Eleştirel İnceleme - M.Y.Y.

\section{REFERENCES}

1. Capela C, Gouveia P, Sousa M, Regadas MJ. Adult diagnosis of Swyer - James - MacLeod syndrome: a case report. J Med Case Rep 201 1; 5:2. [CrossRef]

2. Abba AA, Al-Mobeireek AF. Clinical spectrum of SwyerJamesMacleod syndrome in adults. Saudi Med J 2003; 24:195-8.

3. Garg R, Aga P, Saheer S, Jabeed P, Singh A, Hassan G, et al. Swyer - James - MacLeod syndrome with ipsilateral herniation of hyperinflated hyperlucent lung. BMJ Case Rep 2011 ; bcr0520114191. [CrossRef]

4. Trimis G, Theodoridou M, Mostrou G, Kakavakis K. Swyer-James (MacLeod's) syndrome following pertussis infection in an infant. Scand J Infect Dis 2003; 35:197-9. [CrossRef]

5. Göktepeli M, Yalçın A, Taydaş $O$. A rare case with longterm asthma diagnosis: Swyer-James Macleod Syndrome. Arch Basic Clin Res 2019; 1:37-40. [CrossRef]

6. Daniel TL, Woodring JH, Vandiviere HM, Wilson HD. Swyer-James syndrome- unilateral hyperlucent lung syndrome. A case report and review. Clin Pediatr (Phila) 1984; 23:393-7. [CrossRef]

7. Şen N, Karataşlı M, et al. Swyer-James-Macleod Syndrome: A Case Report. Turkiye Klinikleri Arch Lung 2007; 8:65-7.

8. Moslehi MA. Unilateral hyperlucent lung. Lung India 2016; 33: 119. [CrossRef] 
9. Ozbudak O, Uslu A, Çilli A. A Case of Swyer-James (Macleod's) Syndrome with Bilateral Involvement. Dicle Tıp Dergisi 2005; 32:36-9.

10. Erkasar F, Caglar E, Demirel K. Bilateral Swyer-James (Macleod's) syndrome. Indian J Pediatr 2002; 69:433-5. [CrossRef]

11. Dirweesh A, Alvarez C, Khan K. A unilateral hyperlucent lung - Swyer-James syndrome: A case report and literature review. Respir Med Case Rep 2017; 20:104-6. [CrossRef]

12. Kaplanoglu H, Kaplanoglu V, Toprak U, Dilli A, Hekimoglu B. A case of Swyer-James-Macleod syndrome associated with middle lobe hypoplasia and arteriovenous malformation. Case Rep Med 2012; 2012:1-4. [CrossRef]

13. Griffiths P, Kumar A, Liatsikos K. Swyer-James-MacLeod syndrome and pulmonary arteriovenous malformations: a rare combination. BMJ Case Rep 2020; 13:e231972. [CrossRef]

14. Hajsadeghi S, Chitsazan M, Pouraliakbar H, Jafarian Kerman S. Swyer-James-Macleod syndrome presenting with pulmonary hypertension. Int Cardio Res J 2010; $4: e 62960$.

15. Asker S, Asker M, Gursu O. Swyer James MacLeod syndrome with an anomalous origin of coronary artery: Case report. Respir Med Case Rep 2013; 9:1-3. [CrossRef]
16. Yilmaz MB, Topologlu S, Akin Y, Guray U, Korkmaz S. Swyer-James syndrome with myocardial bridge: a case report. Int J Cardiol 2003; 91:103-5. [CrossRef]

17. Demirkan B, Guray Y, Guray U, Korkmaz S. Ventricular septal defect and SwyerJames (Macleod's) syndrome together: a case report. Int J Cardiol 2006; 113:E4-6. [CrossRef]

18. Akgedik R, Karamanli H, Aytekin I, Kurt AB, Öztürk H, Dağı CE. Swyer-James-Macleod syndrome mimicking an acute pulmonary embolism: a report of six adult cases and a retrospective analysis. Clin Respir J 2018; 12:4049. [CrossRef]

19. Sharma GV, Folland ED, Mclntyre KM, Sasahara AA. Long-term benefit of thrombolytic therapy in patients with pulmonary embolism. Vasc Med 2000; 5: 91-5. [CrossRef]

20. Martin C, Sobolewski K, Bridgeman P, Boutsikaris D. Systemic thrombolysis for pulmonary embolism: a review. $P$ T 2016; 41 : 770-5.

21. Wasmuth JC, Oliver y Miñarro D, Homrighausen A, Leifeld L, Rockstroh JK, Saverbruch T, et al. Phospholipid autoantibodies and the antiphospholipid antibody syndrome: diagnostic accuracy of 23 methods studied by variation in ROC curves with number of clinical manifestations. Clin Chem 2002; 48:1004-10. [CrossRef]

22. Bustamante JG, Singhal M. Antiphospholipid Syndrome (Antiphospholipid Antibody Syndrome, APS, APLS). In: StatPearls. Treasure Island (FL): StatPearls Publishing; 2019. 